\title{
LETTERS
}

\section{An Integrated Genetic Map of the Pearl Locus of Mouse Chromosome 13}

\author{
Albert B. Seymour, ${ }^{1,2}$ Brenda L. Yanak, ${ }^{2}$ Edward P. O'Brien, ${ }^{3}$ \\ Michael E. Rusiniak, ${ }^{3}$ Edward K. Novak, ${ }^{3}$ Larry H. Pinto, ${ }^{4}$ \\ Richard T. Swank, ${ }^{3}$ and Michael B. Gorin ${ }^{1,2,5}$
}

\author{
${ }^{1}$ Departments of Human Genetics, and ${ }^{2}$ Ophthalmology, University of Pittsburgh, Pittsburgh, \\ Pennsylvania 15213; ${ }^{3}$ Molecular and Cellular Biology Department, Roswell Park Cancer Institute, Buffalo, \\ New York 14263; ${ }^{4}$ Neurobiology Department, Northwestern University, Evanston, Illinois 60201
}

We have used a Mus domesticus/spretus congenic animal and two interspecific backcross panels to map genetically 30 sequence-tagged sites (STSs) and 13 genes to the vicinity of the pearl locus on mouse chromosome 13. The STSs defining the mapped region are from DI3Mit9 to DI3Mit37, spanning $10.6 \mathrm{cM}$. Genes mapped to this region include Versican (Cspg2), GTPase activating protein (Rasa), dihydrofolate reductase (Dhfr), arylsulfatase (As-1), thrombin receptor (Cf2r), hexosaminidase b(Hexb), 3-hydroxy-3methylglutaryl coenzyme A reductase (Hmgcr), microtubule associated protein 5/1b (Mtap5), phosphodiesterase (Pde), phosphatidylinositol 3' kinase (Pik3rl), rat integrin al-subunit (Itgal), collagen receptor a2-subunit (Itga2), and 5-hydroxytryptamine la receptor (Htrla). This high resolution genetic map of the pearl region of chromosome 13 establishes the order of multiple markers, including genes whose human homologs are located within a limited region of human chromosome 5, with respect to the phenotypic anchor marker pearl.

The mouse pearl mutation is a recessive, hypopigmentation mutation that affects retinal development and function, and causes inherited platelet storage pool deficiencies (Balkema et al. 1983; Linden and Pinto 1985; O'Brien et al. 1995). Pearl has been studied as a model of human inherited congenital stationary night blindness and the inherited human HermanskyPudlak Syndrome. Originally identified in 1954 in a $\mathrm{C} 3 \mathrm{H}$ strain, it has subsequently been transferred into a C57Bl/6J line, C57Bl/6J PIN pe/pe (Avner et al. 1988). The pearl locus was first localized to chromosome 13 by linkage to Arylsulfatase $B$ and Lth1 (Elliott et al. 1985). Because of its heritable visual phenotype, pearl served as an anchor locus for other genes and markers that have been mapped to chromosome 13 (Holcombe et al. 1991; O'Brien et al. 1995; Xu et al. 1996).

In an effort to further localize the pearl locus, a congenic strain, B6/spretus pe ${ }^{+\mathrm{PIN}} \mathrm{N} 12 \mathrm{~F} 6$, was

${ }^{5}$ Corresponding author

E-MAlL Gorin@vision.eei.upmc.edu; FAX (412) 647-5880. developed to introduce a highly polymorphic region suitable for the mapping of new markers to the pearl region (Rikke et al. 1993). The selective breeding of a region of Mus spretus containing the pearl locus into a C57Bl/6J background allowed for the binning of genes and other markers to within or outside a $10.0-\mathrm{cM}$ interval that contains the pearl locus.

Interspecific backcross panels have been developed to allow high resolution recombinant mapping (Copeland and Jenkins 1991). Markers that are in the pearl region have been localized partly by using a 96-mouse interspecific backcross panel of $\mathrm{C} 57 \mathrm{Bl} / 6 \mathrm{~J}$ and $M$. spretus from Jackson Laboratories. A 528-mouse backcross panel segregating pearl, muted, and satin phenotypes mapped pearl to within a $1.4-\mathrm{cM}$ region $\left(\mathrm{O}^{\prime} \mathrm{Brien}\right.$ et al. 1995). This panel has subsequently been propagated to 1250 mice and the pearl region is now localized to within $0.5 \mathrm{cM}$.

We have integrated mapping data from these sources as part of our efforts to define the critical pearl region with respect to the closest flanking markers. This integrated map establishes the or- 
der of multiple genes and microsatellite markers on chromosome 13.

\section{RESULTS}

The congenic $\mathrm{B} 6 /$ spretus pe ${ }^{+\mathrm{PIN}} \mathrm{N} 12 \mathrm{~F} 6$ mouse strain contains a $10-\mathrm{cM}$ genomic region of $M$. spretus DNA surrounding the pearl locus with a small flanking region of $\mathrm{C} 3 \mathrm{H}$ genomic DNA from the original pearl strain. The remainder of its genome is derived from $\mathrm{C} 57 \mathrm{Bl} / 6 \mathrm{~J}$. Forty microsatellites and sequence-tagged sites (STSs) with nine expressed genes were typed in M. spretus $\mathrm{C} 57 \mathrm{Bl} / 6 \mathrm{~J}$ and $\mathrm{C} 3 \mathrm{H}$ strains to determine the boundaries of the spretus genomic region containing the pearl gene. STS markers PL2, PL3, D13SH1, D13Gor2, D13Gor3, D13Gor4, D13Mit27, D13Mit28, D13Mit29, D13Mit105, D13Mit106, D13Mit107, D13Mit160, D13Mit161, D13Mit169, D13Mit258, D13Mit104, D13Mit69, D13Mit145, D13Mit191, D13Mit36, D5S39 (human), and mouse genes Dhfr, Hexb, As-1, Hmgcr, Rasa, and Mtap5 were binned within the 10 -cM interval. Htr $1 a$ and Ctla 3 were binned telomeric to the 10cM interval.

Southern hybridization with the probe for Srd5 alpha revealed a $1.7-\mathrm{kb}$ informative allele in the congenic that matched the $\mathrm{C} 3 \mathrm{H}$ parental strain. We were unable to distinguish whether the position of Srd5 alpha, based on the Southern blot data, was centromeric or telomeric to the $M$. spretus region. We have placed it in the proximal C3H region based on the 1993 and 1994 consensus maps (Justice and Stephenson 1993, 1994) and a previous study that localized Srd5 alpha centromeric with respect to As-1 and Rasa (Jenkins et al. 1991), which we have binned into the $M$. spretus region.

The strain of origin of most alleles could be determined by directly comparing the products of the appropriate parental DNAs. D13Mit36, however, identified an allele in the congenic B6/ spretus $\mathrm{pe}^{+\mathrm{PIN}} \mathrm{N} 12 \mathrm{~F} 6$ mouse that could either be attributed to M. spretus or $\mathrm{C} 57 \mathrm{Bl} / 6 \mathrm{~J}$. Examination of the locus in the original C57Bl/6J PIN pe/pe mouse showed that the D13Mit36 allele corresponded to the $\mathrm{C} 3 \mathrm{H}$ allele rather than to the $\mathrm{C} 57 \mathrm{Bl} / 6 \mathrm{~J}$ allele. We concluded that the observed allele for D13Mit36 in the congenic was specific for M. spretus. In contrast, D13Mit37, which is telomeric to D13Mit36, identified a $\mathrm{C} 3 \mathrm{H}$ allele in both the congenic and C57Bl/6J PIN pe/pe. Taken together, this indicates that the boundary of the $M$. spretus region in this con- genic strain must lie between D13Mit36 and D13Mit37.

We mapped Dhfr, Pik3rI, and several microsatellites onto the Jackson $[(\mathrm{c} 57 \mathrm{~B} 1 / 6 \mathrm{~J} \times$ spretus $)$ $\mathrm{F}_{1} \times M$. spretus] (BSS) interspecific backcross panel. These data are shown in Figure 1. The marker positions were calculated using Map manager v. 2.6. Marker order was determined by minimizing the number of multiple recombination events. Dhfr showed a band shift when analyzed by single-strand conformation polymorphism (SSCP); C57Bl/6J revealed a higher mobility band than $M$. spretus. Pik $3 r I$ revealed a T-C polymorphism at nucleotide 2833 in the untranslated region between $\mathrm{C} 57 \mathrm{Bl} / 6 \mathrm{~J}$ and $M$. spretus, respectively. This single-base polymorphism was not consistently informative by SSCP analysis, therefore a PCR-based sequence analysis was performed to determine its segregation throughout the backcross panels. The resolution of this panel is $7.9 \mathrm{cM}$ at the $95 \%$ confidence level.

We further localized the pearl region with the interspecific backcross panel described by O'Brien et al. (1995). This panel, originally de-

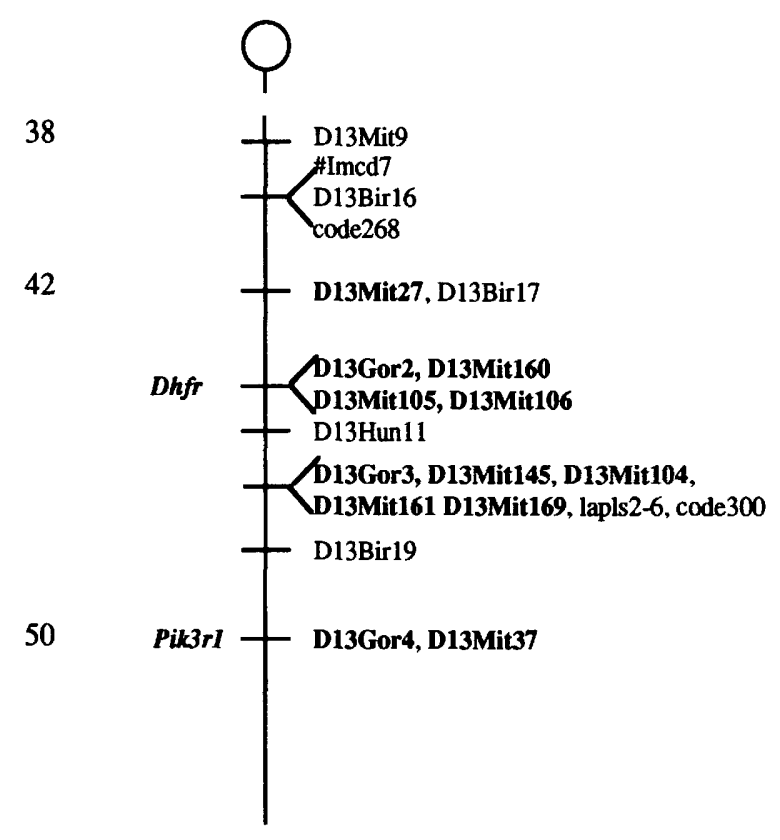

Figure 1 Genetic map of mouse chromosome 13 configured by Jackson Laboratories, showing the positions and relative distances of STS markers and two genes in the pearl region. Highlighted markers were mapped in our laboratory. Numbers at left indicate distances in centimorgans. Information regarding these markers can be obtained from Jackson Laboratories. 


\section{SEYMOUR ET AL.}

scribed with 528 mice, has been expanded to 1250 mice. It has a resolution of $0.08 \mathrm{cM}$ with a $95 \%$ confidence interval up to $0.2 \mathrm{cM}$. The results from this backcross panel are summarized in Figure 2. These data place the pearl critical region to within a $0.5-\mathrm{cM}$ region with the closest flanking markers being Centromere-D13Mit28, D13Mit29-(0.3cM)-Pearl-(0.0cM)-D13Mit160, D13Mit258, D13Mit104, D13Mit161, D13Mit169, D13Mit108-(0.2cM)-Cf2rTelomere. The T-C polymorphism detected in Pik3rI between $M$. spretus and C57Bl/6J, using the Jackson panel, was also observed between SatinMuted-Pearl (SaMuPe) and PWK, respectively. Dhfr analysis by SSCP produced higher mobility bands in the PWK DNA when compared with SaMuPe DNA. The $C f 2 r$ PCR product differed by 20 bp between PWK ( 340 bp) and SaMuPe (320 $\mathrm{bp})$, using primers that flank a GA repeat within the (n-2) intron.

\section{DISCUSSION}

High resolution genetic mapping is an essential step in the positional cloning of any disease gene. With the concentration of highly polymorphic microsatellites increasing rapidly, this approach becomes increasingly powerful. The specific breeding of mice with visual heritable phenotypes has provided the meiotic events necessary to genetically map markers using the visual phenotype as an anchor locus (Holcombe et al. 1991; O'Brien et al. 1995; Xu et al. 1996). We have used two mapping tools that take advantage of the heritable pearl phenotype and the integration of an interspecific backcross panel of $\mathrm{C} 57 \mathrm{Bl} / 6 \mathrm{~J}$ and $M$. spretus to construct a genetic map of the pearl region of chromosome 13.

The congenic $\mathrm{B} 6 /$ spretus $\mathrm{pe}^{+\mathrm{PIN}} \mathrm{N} 12 \mathrm{~F} 6$ enabled us to bin genes and other markers into a limited region including and flanking the pearl locus. The 96-mouse BSS interspecific backcross panel increased the resolution and aided in the ordering of the markers. However, because of the low number of informative meioses, the resolution was only $7.9 \mathrm{cM}$ at the $95 \%$ confidence level. The 1250-mouse interspecific backcross panel of PWK and SaMuPe has increased the resolution to $0.2 \mathrm{cM}$ at the $95 \%$ confidence level.

This integrated map identifies a number of potential discrepancies with the published consensus map (Justice and Stephenson 1994), primarily not with the order of marker sets, but with the alignment of the pearl locus and genes with

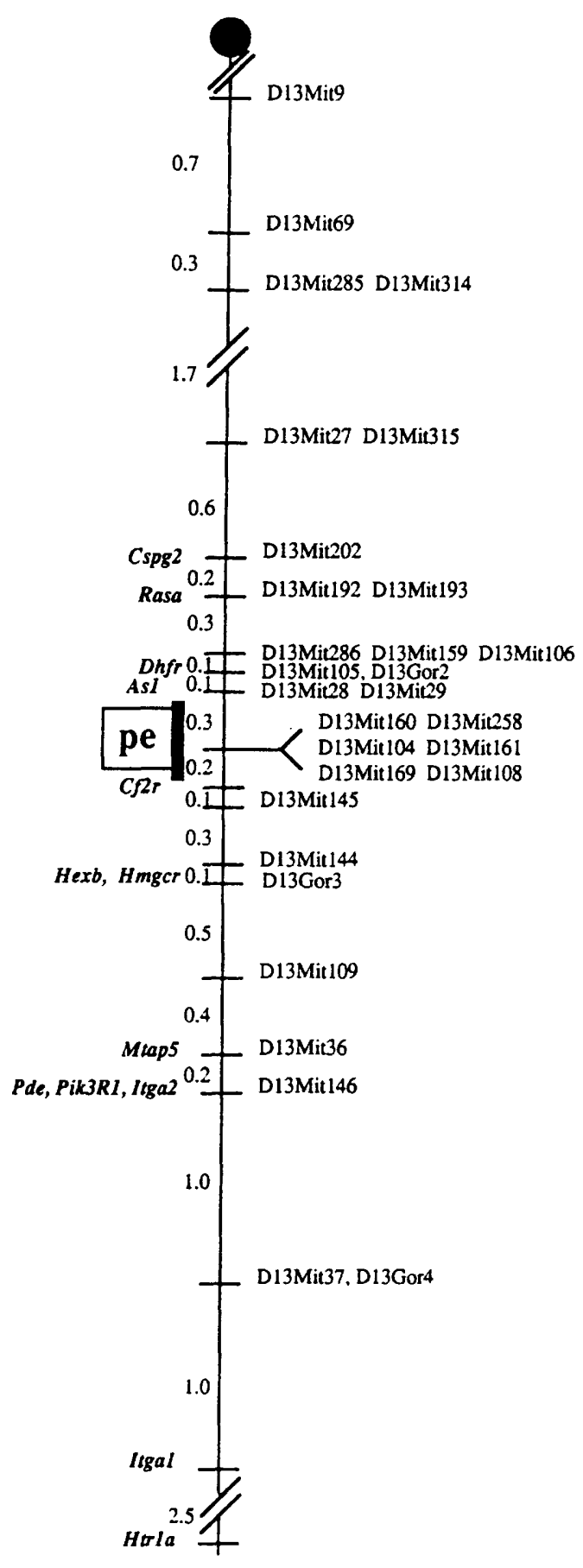

Figure 2 Genetic map of the pearl region of mouse chromosome 13 developed by using the PWK $\times$ SaMuPe interspecific backcross panel of 1250 mice. Numbers at left indicate distances in centimorgans.

respect to the microsatellite markers. We mapped Hexb telomeric to the pearl locus by $0.7 \mathrm{cM}$, and nonrecombinant with D13Gor3. We have further refined the initial mapping of Pik3r1 (Hoyle et al. 
1994) to $1.8 \mathrm{cM}$ telomeric to the set of markers nonrecombinant with the pearl locus. D13Mit28 and D13Mit29 are nonrecombinant with each other in this panel and D13Mit105 and D13Mit 106 are $0.1 \mathrm{cM}$ and $0.2 \mathrm{cM}$ centromeric to D13Mit28/29, respectively. D13Mit104 has been placed telomeric to D13Mit105 by $0.4 \mathrm{cM}$ and telomeric to D13Mit106 by $0.6 \mathrm{cM}$. The positions of D13Mit145, D13Mit144, and D13Mit109 have been localized to $0.3,0.6$, and $1.2 \mathrm{cM}$, respectively, telomeric to D13Mit161. In the Jackson backcross panel we identified a recombination between D13Mit160 and the pearl locus. A similar recombination event has not been observed in the 1250-mouse interspecific backcross panel. Because of the higher resolution of this panel, we have placed D13Mit160 centromeric but closer to D13Mit258, D13Mit104, D13Mit161, D13Mit169, and D13Mit108.

Many of the genes that we placed on this map were potential candidate genes for the pearl mutation, specifically Cspg2, Rasa, Itga2, and Pik3r1. The mapping results have eliminated these, as well as the other mapped genes, as candidate genes based on recombination events from the pearl locus.

All of the genes that we have placed in the region of the pearl locus on mouse chromosome 13 have been associated with a limited region of human chromosome 5 . The orders of these genes and their respective genetic distances on the human genome have not been established. Although it is likely that this region of mouse chromosome 13 is syntenic with human $5 q 13$, further human genome physical mapping efforts will be necessary to establish if small rearrangements distinguish these regions of the two genomes.

The human spinal muscular atrophy (SMA) locus is telomeric to the syntenic pearl region of mouse chromosome 13 based on the human chromosome 5 mapping data. MAP1B, the human homolog of Mtap5, which shows linkage to the human SMA locus is $1.6 \mathrm{cM}$ distal to the pearl region. It has been reported that this region of the genome is very unstable with regards to genomic rearrangements (Selig et al. 1995). One pearl lineage has been reported to have a spontaneous reversion rate of $0.5 \%$ (Pinto et al. 1985), suggesting that, at least for one pearl allele, the disease phenotype could be caused by a DNA insertion. Elucidation of the actual pearl gene and the characterization of the different pearl mutations may clarify this potential genomic instability with respect to this gene.
The high resolution mapping and the abundance of markers in this region allow the initiation of physical mapping techniques to identify the gene responsible for the pearl phenotype as well as providing a set of markers that can be used in the mapping of other genes to this region of mouse chromosome 13.

\section{METHODS}

The interspecific backcross panel of PWK and SaMuPe has been described previously (O'Brien et al. 1995). The pearl (pearl PIN ${ }^{\text {pe/pe }}$ ) and congenic B6/spretus pe ${ }^{+P_{\text {PIN }}} \mathrm{N} 12 \mathrm{~F} 6$ have been described previously (Avner et al. 1988; Rikke et al. 1993). The $\mathrm{C} 3 \mathrm{H}, \mathrm{C} 57 \mathrm{Bl} / 6 \mathrm{~J}$ mice and the 96 -mouse backcross panel of BSS, were purchased from Jackson Laboratories.

Genomic DNA was isolated from mouse spleen and kidney according to standard protocols (Sambrook et al. 1989; Taylor and Rowe 1989). For Southern blotting, $10 \mu \mathrm{g}$ of mouse genomic DNA was digested with EcoRI, PstI, BamHI, BglII, or HindIII according to manufacturer's conditions. The digests were electrophoresed on $1.0 \%$ agarose (FMC), stained with EtBr, and transferred to Hybond N+ filters (Amersham). The DNA was immobilized at $80^{\circ} \mathrm{C}$ for $2 \mathrm{hr}$. The hybridizations were performed as described previously (Xu et al. 1996). Markers were determined to be within the pearl-containing $M$. spretus region of the congenic animal if the hybridization patterns of the congenic animal were identical to those of $M$. spretus and distinct from the C57Bl/6J background.

Candidate genes that have been mapped previously to mouse chromosome 13 or localized to a presumed syntenic region of human chromosome 5 were used to determine their position with respect to the pearl locus. The probes are described in Table 1 . All probes were excised from the vector with the appropriate enzyme, separated by gel electrophoresis on $1.0 \%$ agarose, excised, and purified with Geneclean (Bio 101, Inc.). The DNA Probes were labeled by the random hexamer method with $\left[\alpha-{ }^{32} \mathrm{P}\right] \mathrm{dCTP}$ (Feinberg and Vogelstein 1983; NEN/Dupont).

D13Mit series primer sets were purchased from Research Genetics. The forward primer for each set was endlabeled with T4 kinase (GIBCO) and $\left[\gamma^{32} \mathrm{P}\right] \mathrm{ATP}$ (NEN/ Dupont). The PCR conditions were $94^{\circ} \mathrm{C}$ for $2 \mathrm{~min}$ followed by 35 cycles of $94^{\circ} \mathrm{C}$ for $30 \mathrm{sec}, 55^{\circ} \mathrm{C}$ for $1 \mathrm{~min}$, and $72^{\circ} \mathrm{C}$ for 1 min with 1 unit of Taq polymerase in $25 \mathrm{~mm}$ TAPS (pH 9.3), $1.5 \mathrm{~mm} \mathrm{MgCl}_{2}, 50 \mathrm{~mm} \mathrm{KCl}, 1 \mathrm{~mm}$ DTT, and $0.2 \mathrm{~mm}$ each of dATP, dCTP, dGTP, and dTTP in a final volume of $20 \mu \mathrm{l}$. Products were electrophoresed on a $6.0 \%$ polyacrylamide, $7 \mathrm{M}$ urea denaturing sequencing gel, dried, and analyzed by autoradiography.

The D13Gor primers were described previously (Xu et al. 1996). The $P i k 3 r 1$ primers are specific for nucleotides 2752-2935 in the 3' untranslated region of phosphatidylinositol 3' kinase regulatory subunit resulting in a product of $184 \mathrm{bp}$. The primer sequences are as follows. Pik3r1F 5'-TTCCTCACCTTCAAGCCACCCAAG-3'; Pik3r1R 5'AGGTTAGAAACGTCTGGTCATCCAAC-3'. The Dhfr primers were OD3PF 5'-ACAGGAAGATGCTTTCAAGTTC-3' and OD3PR 5'-GAGGTCTCATGGGAGGGG-3'. Thrombin receptor (CF2r), D13SH1, PL2, and PL3 primer sequences 
Table 1. Genes Mapped to the Pearl Region of Mouse Chromosome 13

\begin{tabular}{|c|c|c|c|c|c|c|}
\hline \multirow[b]{2}{*}{ Gene } & \multirow{2}{*}{$\begin{array}{l}\text { Probe } \\
\text { name }\end{array}$} & \multicolumn{2}{|c|}{ Enzyme $^{a}$} & \multicolumn{2}{|c|}{ Informative alleles ${ }^{d}$} & \multirow[b]{2}{*}{ Reference } \\
\hline & & congenic $^{b}$ & PWK $^{c}$ & congenic & PWK & \\
\hline Versican & Cspg2 & N.D. ${ }^{e}$ & Kpnl & N.D. & $14.5,9.4$ & $\begin{array}{l}\text { Zimmermann and } \\
\text { Ruoslahti (1988) }\end{array}$ \\
\hline $\begin{array}{l}\text { GTPase-activating } \\
\text { protein }\end{array}$ & Rasa & EcoRI & HindlII & 19.1 & 4.8 & Hsieh et al. (1989) \\
\hline Arysulfatase B & As1 & BamHI & EcoRI & 12.3 & $22,9.0,7.5$ & $\begin{array}{l}\text { Schuchman et al. } \\
\text { (1990) }\end{array}$ \\
\hline Hexosaminidase B & HexB & BamHI & Pstl & $16.4,5.4$ & 4.5 & Bapat et al. (1988) \\
\hline $\begin{array}{l}\text { 3-hydroxy- } \\
\text { 3-methylglutaryl } \\
\text { coenzyme A } \\
\text { reductase }\end{array}$ & Hmgcr & N.D. & Kpnl & N.D. & 6.4 & $\begin{array}{l}\text { Sundaresan et al. } \\
\text { (1989) }\end{array}$ \\
\hline $\begin{array}{l}\text { Microtube-associated } \\
\text { protein } 5 / 1 \mathrm{~B}\end{array}$ & Mtap5 & EcoRI & $X b a l$ & 4.5 & 9.6 & $\begin{array}{l}\text { Garner et al. } \\
\quad(1990)\end{array}$ \\
\hline $\begin{array}{l}\text { Cyclic nucleotide } \\
\text { phosphodiesterase }\end{array}$ & Pde & N.D. & HindIII & N.D. & 12.0 & $\begin{array}{l}\text { Milatovich et al. } \\
\text { (1994) }\end{array}$ \\
\hline $\begin{array}{l}\text { Collagen receptor a } 2 \\
\text { subunit }\end{array}$ & $\operatorname{ltga} 2$ & N.D. & $B g / I$ & N.D. & 6.0 & $\begin{array}{l}\text { Takada and Hemler } \\
\text { (1989) }\end{array}$ \\
\hline $\begin{array}{l}\text { Rat integrin } \\
\text { a1-subunit }\end{array}$ & Itga1 & N.D. & Pstl & N.D. & 9.6 & $\begin{array}{l}\text { Ignatius et al. } \\
(1990)\end{array}$ \\
\hline $\begin{array}{l}\text { 5-hydroxytryptamine } \\
\text { (serotonin) 1a receptor }\end{array}$ & Htr1a & EcoRI & BgflI & 1.2 & 4.9 & $\begin{array}{l}\text { Kobilka et al. } \\
\text { (1987) }\end{array}$ \\
\hline Steroid $5 \alpha$-reductase & Srd5alpha & $B g / l$ & N.D. & 1.7 & N.D. & $\begin{array}{l}\text { Jenkins et al. } \\
\text { (1991) }\end{array}$ \\
\hline $\begin{array}{l}\text { Cytotoxic T } \\
\text { lymphocyte- } \\
\text { associated sequence } 3\end{array}$ & Ctla3 & EcoRI & N.D. & $24.5,13.5$ & N.D. & $\begin{array}{l}\text { Gershenfeld and } \\
\text { Weismann } \\
(1986)\end{array}$ \\
\hline $\begin{array}{l}\text { aEnzyme used to digest genon } \\
{ }^{b} \text { Genomic DNA from the cong } \\
\text { cGenomic DNA from PWK was } \\
{ }^{d} \text { Allele sizes in kilobases (kb). } \\
\text { e(N.D.) Not determined. }\end{array}$ & $\begin{array}{l}\text { ic DNA to ider } \\
\text { enic strain was } \\
\text { compared to }\end{array}$ & $\begin{array}{l}\text { compared } t \\
\text { SaMuPe to ol }\end{array}$ & ve cro & $s$ in the ba & $\begin{array}{l}\text { s described in } \\
\text { kcross panel. }\end{array}$ & ext. \\
\hline
\end{tabular}

have been described previously (Casavant and Hardies 1993; Rikke et al. 1993; Poirier et al. 1996). The PCR conditions for Dhfr were identical to those for the D13Mit series. The PCR conditions for Pik3r1 required an annealing temperature of $60^{\circ} \mathrm{C}$.

SSCP analysis for Dhfr was done per standard protocol with a few modifications (Dracopoli et al. 1994). Samples were denatured in $98 \%$ formamide $/ 0.025 \%$ bromphenol blue $/ 0.025 \%$ xylene cyanol and $0.65 \mathrm{~mm} \mathrm{NaOH}$ at $95^{\circ} \mathrm{C}$ for $5 \mathrm{~min}$ and electrophoresed on a $0.5 \times$ MDE gel (Hydrolink) overnight at $4.0^{\circ} \mathrm{C}$. The gel was dried and analyzed by autoradiography.

DNA sequencing of PCR products was performed using a cycle sequencing kit (Epicentre). Primers were endlabeled as described above. The products were separated on a $6.0 \% 7 \mathrm{~m}$ urea denaturing sequencing gel, dried, and analyzed by autoradiography.

\section{ACKNOWLEDGMENTS}

We thank Drs. Lucy Rowe and Mary Barter at Jackson
Laboratory for assistance in the mapping on the Jackson backcross panel, and we are grateful to Dr. Stephen C. Hardies at The University of Texas Health Science Center for providing Dhfr primers (OD3PF, OD3PR) and critically reading this manuscript. This work was supported by National Institutes of Health (NIH) grant EY9192, National Eye Institute Core grant EYO8098, and Eye and Ear Foundation of Pittsburgh (M.B.G.), NIH grant EY01221 (L.H.P.) and National Heart, Lung, and Blood Institute grant HL31698 (R.T.S.).

The publication costs of this article were defrayed in part by payment of page charges. This article must therefore be hereby marked "advertisement" in accordance with 18 USC section 1734 solely to indicate this fact.

\section{REFERENCES}

Avner, P., L. Amar, L. Dandolo, and J.L. Cuenet. 1988. Genetic analysis of the mouse using interspecific crosses. Trends Genet. Rev. 4: 18-23. 
Balkema, G.W., N.J. Mangini, and L.H. Pinto. 1983. Discrete visual defects in pearl mutant mice. Science 219: 1085-1087.

Bapat, B., M. Ethier, K. Neote, D. Mahuran, and R.A. Gravel. 1988. Cloning and sequence ananlysis of a cDNA encoding the beta-subunit of mouse beta-hexosaminidase. FEBS Lett. 237: 191-195.

Casavant, N.C. and S.C. Hardies. 1993. Targeted cloning of a subfamily of LINE-1 elements by subfamily-specific LINE-1-PCR. Mamm. Genome 4: 193-201.

Copeland, N.G. and N.A. Jenkins. 1991. Development and applications of a molecular genetic linkage map of the mouse genome. Trends Genet. 7: 113-118.

Dracopoli, N.C., J.L. Haines, B.R. Korf, D.T. Moir, C.C. Morton, C.E. Seidman, J.G. Seidman, and D.R. Smith, eds. 1994. Searching candidate genes for mutations. In Current protocols in human genetics. Chap. 7, pp. 7.4.1-7.4.6. John Wiley/Greene, New York, NY.

Elliott, R.W., W.L. Daniel, B.A. Taylor, and E.K. Novak. 1985. Linkage of loci affecting a murine liver protein and arylsulfatase $\mathrm{B}$ to chromosome $13 . J$. Heredity 76: $243-246$.

Feinberg, A.P. and B. Vogelstein. 1983. A technique for radiolabeling DNA restriction endonuclease fragments to high specific activity. Anal. Biochem. 132: 6-13.

Garner, C.C., A. Garner, G. Huber, C. Kazak, and C. Matus. 1990. Molecular cloning of microtubuleassociated protein 1 (MAP1A) and microtubuleassociated protein 5 (MAP1B): Identification of distinct genes and their differential expression in developing brain. J. Neurochem. 55: 146-154.

Gershenfeld, H.K. and I.L. Weissman. 1986. Cloning of a cDNA for a $\mathrm{T}$ cell-specific serine protease from a cytotoxic T lymphocyte. Science 232: 854-858.

Holcombe, R.F., D.A. Stephenson, A. Zweidler, R.M. Stewart, V.M. Chapman, and J.G. Seidman. 1991. Linkage of loci associated with two pigment mutations on mouse chromosome 13. Genet. Res. Camb. 58: 41-50.

Hoyle, J., I.G. Yulug, S.E. Egan, and E.M.C. Fisher. 1994. The gene that encodes the phosphatidylinositol-3 kinase regulatory subunit (p85 alpha) maps to chromosome 13 in the mouse. Genomics 24: $400-402$.

Hsieh, C.-L., U.S. Vogel, R.A.F. Dixon, and U. Francke. 1989. Chromosome localization and cDNA sequence of murine and human genes for ras p21 GTPase activating protein (GAP). Somat. Cell \& Mol. Genet. 15: 579-590.

Ignatius, M.J., T.H. Large, M. Houde, J.W. Tawil, A. Barton, F. Esch, S. Carbonetto, and L.F. Reichardt. 1990. Molecular cloning of the rat integrin $\mathrm{a}_{1}$-subunit: $\mathrm{A}$ receptor for laminin and collagen. J. Cell Biol.

111: $709-720$.
Jenkins, E.P., C.-L. Hsieh, A. Milatovich, K. Normington, D.M. Berman, U. Francke, and D.W. Russell. 1991.

Characterization and chromosomal mapping of a human steroid 5 alpha-reductase gene and pseudogene and mapping of the mouse homolog. Genomics

11: $1102-1112$.

Justice, M.J. and D.A. Stephenson. 1994. Mouse chromosome 13. Mamm. Genome 5: S196-S206.

\begin{abstract}
1993. Mouse chromosome 13. Mamm. Genome 4: $\mathrm{S} 192-\mathrm{S} 202$

Kobilka, B.K., T. Frielle, S. Collins, T. Yang-Feng, T.S. Kobilka, U. Francke, R.J. Lefkowitz, and M.G. Caron. 1987. An intronless gene encoding a potential member of the family of receptors coupled to guanine nucleotide regulatory proteins. Nature 329: 75-79.
\end{abstract}

Linden, R. and L.H. Pinto. 1985. Developmental genetics of the retina: Evidence that the pearl mutation in the mouse affects the time course of natural cell death in the ganglion cell layer. Exp. Brain Res. 60: 79-86.

Milatovich, A., G. Bolger, T. Michaeli, and U. Francke. 1994. Chromosome localizations of genes for five cAMP-specific phosphodiesterases in man and mouse. Somat. Cell \& Mol. Genet. 20: 75-86.

O'Brien, E., E. Novak, L. Zhen, K. Manly, D. Stephenson, and R. Swank. 1995. Molecular markers near two mouse chromosome 13 genes, muted and pearl, which cause platelet storage pool deficiency. Mamm. Genome 6: $19-24$

Pinto, L.H., M.A. Williams, H. Suzuki, N. Mangini, G.W. Balkema Jr., and J.W. Vanable Jr. 1985. Visual defects in mouse hypopigmentation mutants. Neurosci. Res. S2: S239-S251.

Poirier, C., E.P. O'Brien, A.L. Brunialti, J.C. Chambard, R.T. Swank, and J.L. Guenet. 1996. The gene encoding thrombin receptor (Cf2r) maps to mouse chromosome 13. Mamm. Genome 7: 322.

Rikke, B.A., L.H. Pinto, M.B. Gorin, and S.C. Hardies. 1993. M. spretus-specific LINE-1 DNA probes applied to the cloning of the murine pearl locus. Genomics 15: 291-296.

Sambrook, J., E.F. Fritsch, and T. Maniatis. 1989. Molecular cloning: A laboratory manual, 2nd ed. Cold Spring Harbor Laboratory Press, Cold Spring Harbor, NY.

Schuchman, E.H., C.E. Jackson, and R.J. Desnick. 1990. Human arylsulfatase B: MOPAC cloning, nucleotide sequence of a full-length CDNA, and regions of amino acid identity with arylsulfatases A and C. Genomics 6: $149-158$.

Selig, S., S. Bruno, J.M. Scharf, C.H. Wang, E. Vitale, T.C. Gilliam, and L.M. Kunkel. 1995. Expressed cadherin pseuodogenes are localized to the critical region of the 


\section{SEYMOUR ET AL.}

spinal muscular atrophy gene. Proc. Natl. Acad. Sci.

92: $3702-3706$.

Sundaresan, S., T.L. Yang-Feng, and U. Francke. 1989. Genes for HMG-CoA reductase and serotonin 1a receptor are on mouse chromosome 13. Somat. Cell \& Mol. Genet. 15: $465-469$.

Takada, Y. and M.E. Hemler. 1989. The primary structure of the VLA-2/collagen receptor alpha 2 subunit (platelet GPIa): Homology to other integrins and the presence of a possible collagen-binding domain. J. Cell Biol. 109: $397-407$.

Taylor, B.A. and L.B. Rowe. 1984. Genes for serum amyloid A proteins map to chromosome 7 in the mouse. Mol. Gen. Genet. 195: 491-499.

Xu, H.P., B.L. Yanak, M.H. Wigler, and M.B. Gorin. 1996. New polymorphic markers in the vicinity of the pearl locus on mouse chromosome 13. Mamm. Genome 7: 16-19.

Zimmermann, D.R. and E. Ruoslahti. 1988. Multiple domains of the large fibroblast proteoglycan, versican. EMBO J. 8: 2975-2981.

Received February 26, 1996; accepted in revised form April 16, 1996. 


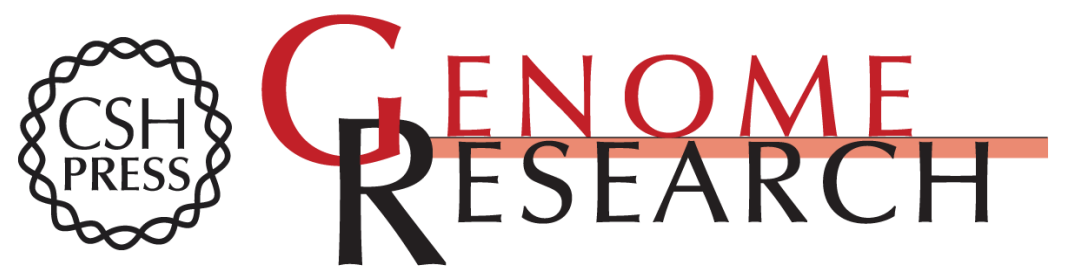

\section{An integrated genetic map of the pearl locus of mouse chromosome 13.}

A B Seymour, B L Yanak, E P O'Brien, et al.

Genome Res. 1996 6: 538-544

Access the most recent version at doi:10.1101/gr.6.6.538

References This article cites 30 articles, 5 of which can be accessed free at:

http://genome.cshlp.org/content/6/6/538.full.html\#ref-list-1

\section{License}

Email Alerting Receive free email alerts when new articles cite this article - sign up in the box at the Service top right corner of the article or click here.

\section{Affordable, Accurate Sequencing.}

To subscribe to Genome Research go to: https://genome.cshlp.org/subscriptions 